\title{
APPROPRIATE DATES OF Trichogramma evanescens (WEST.) RELEASE TO CONTROL RICE STEM BORER, AND EFFECT OF SPRAYED CHEMICALS ON PARASITOID SURVIVAL \\ El-Habashy, M.M. \\ Rice Research and Training Center (RRTC), Field Crops Research Institute, Agricultural Research Center, Egypt.
}

\begin{abstract}
A schedule was investigated to find out the most appropriate date (or dates) for releasing Trichogramma evanescens (West.) to control the rice stem borer, Chilo agamemnon Bles. in rice fields. Due to release, the average reductions in dead hearts were $54.11,24.22$ and $63.30 \%$ with releases on 20 June, 5 July and 20 June +5 July, respectively. The average reductions in white heads ranged from 28.35 , to 81.67 $\%$ due to one, two or three releases. However, two releases on 5 July +20 July or on 20 July +5 August achieved a satisfactory borer control, resulting in 71.09 and 74.13 $\%$ reductions in white heads. In a large-scale experiment conducted in the farmers' fields (a total of 52 feddans at Dakahlia and Kafr El-Sheikh Governorates), the reductions in dead hearts were $87.33 \%$ due to the parasitoid release compared to $58.97 \%$ due to insecticide application, while those of white heads were 94.38 and $46.28 \%$, respectively. In a laboratory test, the chemicals (nutrients and fungicides), commonly used in rice cultivations, were found safe when sprayed onto the parasitoid confined in Sitotroga cerealella (Oliv.) eggs (enveloped or nonenveloped). Only the insecticide, Malathion was toxic; 17.89 and $100 \%$ parasitoid mortality for the enveloped and nonenveloped parasitoid, respectively. When the emerging parasitoid adults were exposed to the chemicals, or even to tap water, all the emerging individuals were killed. These findings show the importance of releasing the parasitoid twice from early July to early August, and to avoid spraying any chemicals onto the emerging $T$. evanescens adults. In all cases, the insecticide applications should be completely forbidden in the release fields.
\end{abstract}

\section{INTRODUCTION}

Rice plants, in Egypt, are subject to infestation with several insect pests, but the most destructive one is the rice stem borer, Chilo agamemnon Bles. The growers use insecticides to control the pest earlier than needed when they watch the dead heart symptom which appears during the vegetative stage. Such insecticide applications are highly hazardous to natural enemies, from which is the egg-parasitoid, Trichogramma spp., that represent important biological elements to control stem borers in rice fields (Marub 1993, Asaady and Navai 1995, Sherif et al 2008).

There are two ways to enhance the population of $T$. evanescens. in rice fields in Egypt. The first way is by conserving the occurring population through avoidance (or minimizing) the use of pesticides. The second one is by mass-rearing the parasitoid to be released at proper rates and proper times. Sherif et al (2008) concluded that the most appropriate rate of $T$. evanescens release is 30,000 individuals / feddan, and to be released twice; 20 and 40 days after transplanting rice plants sown by the first week of May. 
$T$. chilonis and $T$. dendrolium have provided better control for the Asian corn borer, Ostrinia furnacalis (Guenee) (Feng et al 1999, Tan 1999 and $\mathrm{Wu}$ et al 2001). The Indian meal moth, Plodia interpunctella was also controlled in food products located in retail stores by the release of Trichogramma deion. The bio-intensive program, including releasing $T$. chilonis, for controlling cotton insects gave best seed cotton yields in farmers fields and the highest net income (Anonymous 1999). Trichogramma release for control of the Asian corn borer has become one of the key techniques of integrated pest management of corn pests in China (Wang et al 2003).

To keep the rice ecosystem clean without the hazardous effect of insecticides, the option of using Trichogramma seems too much appropriate. Thus, the current study was conducted to find out the appropriate time and number of Trichogramma releases in rice fields to control the stem borer, $C$. agamemnon. Also, the effect of some chemicals on the mortality of the parasite was laboratory tested. On the large scale, the efficiency of insecticides (e.g. carbofuran) and biological control (e.g. T. evanescens) against the rice stem borer was compared.

\section{MATERIALS AND METHODS}

Experiments were conducted to find out the efficiency of Trichogramma evanescens (West.) to control the rice stem borer, Chilo Agamemnon (Bles.) as compared with the insecticides. Also, sensitivity of the parasitoid to applied chemicals in rice fields was investigated.

\section{Field experiment:}

This experiment was carried out at the experimental farm of Rice Research and Training Center (RRTC), Sakha, Kafr El-Sheikh Governorate during 2007 and 2008 rice seasons. The experiment aimed to finding out the appropriate schedule of releasing the egg-parasitoid, $T$. evanescens in rice fields to control the rice stem borer, C. agamemnon on Giza 178 rice cultivar, as a susceptible check to the rice stem borer (Anonymous 2007) was sown on 5 May, and transplanted one month later as recommended. All recommendations of rice cultivation were adopted but without any insecticides and fungicides. The experimental field was divided into ten plots (one feddan each), and the release was applied in the rice plots which were about 100 meter apart. The plots received $T$. evanescens at a rate of 30,000 parasitoids / fed / release (Sherif et al 2008).

To evaluate the percentages of dead hearts, a sample of 30 hills per plot (10 hills $\times 3$ subsamples) was taken from each treatment two weeks after release. To evaluate the percentages of white heads, a sample of the same size was taken three weeks before harvest. Reductions of dead hearts and white heads (two main symptoms of rice stem borer) in the release plots were calculated on the basis of borer infestation in the check plot (with no release).

\section{Laboratory experiment:}

Rice growers spray several chemicals in rice fields during the growing season. Some of these chemicals are nutrients, and some others are pesticides. So, a laboratory experiment was conducted to find out the effect 
of such chemicals on the survival of Trichogramma that could be released in the rice fields. Six treatments, in addition to a check, were practiced upon three forms of $T$. evanescens according to as follows:

1. Enveloped small paper $\left(4 \mathrm{~cm}^{2}\right)$ glued on which the eggs of $S$. cerealella harbouring alive pupae of $T$ evanescens..

2. The same as the previous one, but the paper having Sitotroga eggs was not enveloped.

3. The emerging adults of $T$. evanescens.

The emerging numbers of $T$. evanescens adults from the six treatments were counted, and the reductions in the emergence due to chemical treatments were calculated as compared to the emergence in the check (untreated).

\section{Large-scale fields treated with $T$. evanescens and insecticides:}

To find out the efficiency of $T$ evanescens. release versus insecticide application in large areas, rice fields at Dakahlia, Kafr El-Sheikh and Gharbia Governorates (total of 52 feddan) were assigned to this experiment. The fields were cultivated with four cultivars; Egyptian Yasmin, Giza 178, Hybrid 1 and Sakha 104. The fields were chosen to be sown within the first week of May and received the same cultural practices. The parasitoid, T. evanescens was released in the areas of 30, 8, 5, 7 and 2 feddans at Mansoura, Manzala, Talkha (Dakahlia Governorate), El-Reiad (Kafr El-Sheikh Governorate) and Kotor (Gharbia Governorate), respectively. The parasitoid was released twice; 20 July and 5 August, each at a rate of 30,000 parasitoids / feddan. At each location, an area of one feddan was assigned to the insecticide application; carbofuran (Furadan $10 \mathrm{G}$ ) at a rate of $2 \mathrm{~kg} /$ fed which is the conventional application of the growers, despite the recommended dose is 6 $\mathrm{kg} / \mathrm{fed}$. The chemical application was practiced twice., on 20 July (the same date of first parasitoid release), and on 5 August (the same date of second release) Percentages of dead hearts were evaluated at the areas treated with $T$. evanescens, treated with the parasite and check (untreated) areas two weeks after treatments. Percentages of white heads were evaluated three weeks prior to harvest.

\section{RESULTS AND DISCUSSION}

\section{Field experiment:}

Data presented in Table (1) show the rice stem borer, Chilo Agamemnon (Bles.) infestation, in forms of dead hearts, as influenced by date of Trichogramma evanescens (West.) release. In 2007 season, the check plot (no release) exhibited $3.17 \%$ dead hearts, which were reduced to 1.76, 2.52 and $1.34 \%$ when the parasitoid was released on 20 June, 5 July, and 20 June plus 5 July, respectively. The statistical analysis revealed highly significant differences among treatments. The corresponding calculated values of dead heart reductions were 44.48, 20.50 and $57.73 \%$. In 2008 season, almost the same trend was found with $63.73,27.94$ and $68.87 \%$ reductions for the three dates of release, respectively with highly significant differences. As an average of both years, the borer infestation reductions were $54.11,24.22$ and $63.30 \%$ when the release was practiced on 20 June, 5 July and 20 June plus 5 July. Similar results of rice stem borer infestation reduction due to the release of Trichogramma spp were reported in the 
experiments. Inundative release of $T$. japonicum in plots of rice at Assam, India reduced the damage by stem borer, Scirpophaga incertulas by $54.90 \%$ after fifty days from release (Borah 1994). Sherif et al (2008) reported 48.83 $\%$ dead heart reduction when the parasitoid was released in rice fields twice; 20 and 40 days after transplanting Giza 178.

Table (1): Rice stem borer $C$. agamemnon infestation as influenced by schedule of $T$. evanescens release in rice fields.

\begin{tabular}{|c|c|c|c|c|c|}
\hline \multirow[b]{2}{*}{ Date of release } & \multicolumn{2}{|c|}{2007 season } & \multicolumn{2}{|c|}{2008 season } & \multirow[b]{2}{*}{$\begin{array}{c}\text { Average } \\
\text { reduction \% }\end{array}$} \\
\hline & $\begin{array}{c}\text { Dead heart } \\
\%\end{array}$ & $\begin{array}{c}\text { Dead heart } \\
\% \\
\text { reduction }\end{array}$ & $\begin{array}{c}\text { Dead heart } \\
\%\end{array}$ & \begin{tabular}{|c|} 
Dead heart \\
$\%$ \\
reduction
\end{tabular} & \\
\hline $\begin{array}{l}\text { Check (no release) } \\
20 \text { June } \\
5 \text { July } \\
20 \text { June + } 5 \text { July } \\
\end{array}$ & $\begin{array}{l}3.17 \mathrm{a}^{*} \\
1.76 \mathrm{~b} \\
2.52 \mathrm{a} \\
1.34 \mathrm{~b} \\
\end{array}$ & \begin{tabular}{|c|}
---- \\
44.48 \\
20.50 \\
57.73 \\
\end{tabular} & $\begin{array}{l}4.08 \mathrm{a} \\
1.48 \mathrm{c} \\
2.94 \mathrm{~b} \\
1.27 \mathrm{c} \\
\end{array}$ & \begin{tabular}{|c|}
---- \\
63.73 \\
27.94 \\
68.87 \\
\end{tabular} & $\begin{array}{c}--- \\
54.11 \\
24.22 \\
63.30 \\
\end{array}$ \\
\hline \begin{tabular}{|r|} 
LSD \\
$5 \%$ \\
$1 \%$ \\
\end{tabular} & $\begin{array}{l}0.491 \\
0.672\end{array}$ & & $\begin{array}{l}0.621 \\
0.940\end{array}$ & & \\
\hline$F$ & $4.660^{\star \star}$ & & $5.320^{\star \star}$ & & \\
\hline
\end{tabular}

* In a column, means followed by the same letter are not significantly different at the $5 \%$ level.

Data in Table (2) show the effect of $T$. evanescens release on the levels of borer infestation as white heads. In 2007 rice season, the check plot (with no release) suffered $12.57 \%$ white heads. Releases on 20 June, 5 July, 20 July or 20 June +5 July reduced the white heads to $6.30,5.86,6.52$ and $7.89 \%$ which means $49.88,53.38,48.13$ and $37.23 \%$ white head reductions, respectively. However, the greatest borer reductions were detected with three releases; 20 July +5 August +20 August ( $82.42 \%$ reduction), 5 July +20 July +5 August ( $2.42 \%$ reduction). In 2008 rice season, a similar trend was obtained. The highest borer reduction $(80.91 \%)$ was detected with three releases; 20 July +5 August +20 August followed by release on 20 June +5 July +20 July $(77.55 \%$ white head reduction), and then by two releases; 20 June +5 July ( $72.80 \%$ reduction). The average of both years of study show that the most appropriate dates of the parasitoid release to control the borer are: 20 July +5 August $(74.13 \%$ reduction), 5 July +20 July +5 August (72.77), while the greatest borer reduction was obtained with the release of 20 July +5 August +20 August $(81.67 \%)$. From the applicable and economic point of view, two releases could be recommended to control the rice stem borer, particularly on 5 July +20 July or on 20 July +5 August $(71.09-74.13$ $\%$ borer reduction). Each release should contain 30,000 parasitoid individuals / fed. Similar reductions in white heads were obtained by Sherif et al (2008) who obtained $69.71 \%$ white head reduction in stem borer infestation when $T$. evanescens was released twice (each at a rate of 30,000 parasitoids / fed); 20 and 40 days after transplanting the rice sown by the first week of May. Soliman and Ewaise (1997) obtained successful C. agamemnon control when $T$. evanescens was released in the rice fields at a rate of 28,000 parasitoids / fed. 
The inundative release of $T$. japonicum during the panicle initiation resulted in a significant increase of parasitism on white stem borer (WSB), Scirpophaga innotata Walker eggs from $12 \%$ before release to $32 \%$ four days after release, resulting in lower WSB damage and a higher yield. (Anonymous 2005).

Table (2): Rice stem borer C. agamemnon infestation as influenced by schedule of Trichogramma evanescens release in rice fields

\begin{tabular}{|c|c|c|c|c|c|}
\hline \multirow[b]{2}{*}{ Date of release } & \multicolumn{2}{|c|}{2007 season } & \multicolumn{2}{|c|}{\begin{tabular}{|l|}
2008 season \\
\end{tabular}} & \multirow[b]{2}{*}{$\begin{array}{c}\text { Average } \\
\text { reduction \% }\end{array}$} \\
\hline & $\begin{array}{c}\text { White head } \\
\%\end{array}$ & $\begin{array}{l}\text { White head } \\
\% \text { reduction }\end{array}$ & \begin{tabular}{|c|} 
White head \\
$\%$
\end{tabular} & $\begin{array}{l}\text { White head } \\
\% \text { reduction }\end{array}$ & \\
\hline Check & $12.57 \mathrm{a}^{*}$ & \begin{tabular}{|l|}
--- \\
\end{tabular} & $10.11 \mathrm{a}$ & ---- & ---- \\
\hline 20 Jun. & $6.30 \mathrm{bc}$ & 49.88 & $9.42 \mathrm{a}$ & 6.82 & 28.35 \\
\hline 5 Jul. & $5.86 \mathrm{bc}$ & 53.38 & $6.35 \mathrm{abc}$ & 37.19 & 45.29 \\
\hline 20 Jul. & $6.52 \mathrm{bc}$ & 48.13 & $8.23 a b$ & 35.41 & 41.77 \\
\hline 20 Jun. + 5 Jul. & $7.89 \mathrm{abc}$ & 37.23 & $2.75 \mathrm{bc}$ & 72.80 & 55.02 \\
\hline 5 Jul. + 20 Jul. & $2.42 \mathrm{c}$ & 80.75 & $3.90 \mathrm{bc}$ & 61.42 & 71.09 \\
\hline 20 Jul. + 5 Aug. & $2.60 \mathrm{c}$ & 79.32 & $3.14 \mathrm{bc}$ & 68.94 & 74.13 \\
\hline 20 Jun. + 5 Jul. + 20 Jul. & $4.68 \mathrm{c}$ & 62.77 & $2.27 \mathrm{bc}$ & 77.55 & 70.16 \\
\hline 5 Jul. + 20 Jul. + 5 Aug. & $2.42 \mathrm{c}$ & 80.75 & $3.56 \mathrm{bc}$ & 64.79 & 72.77 \\
\hline 20 Jul. + 5 Aug. 20 Aug. & $2.21 \mathrm{c}$ & 82.42 & $1.93 \mathrm{c}$ & 80.91 & 81.67 \\
\hline \multicolumn{6}{|l|}{ LSD } \\
\hline $5 \%$ & 4.908 & & 5.474 & & \\
\hline $1 \%$ & 6.724 & & 7.499 & & \\
\hline$F$ & $4.66^{\star \star}$ & & $3.492^{\star *}$ & & \\
\hline
\end{tabular}

${ }^{*}$ In a column, means followed by the same letter are not significantly different at the $5 \%$ level.

\section{Laboratory experiment:}

The effects of different chemicals; nutrients and pesticides on the survival of $T$. evanescens are shown in Table (3). In case of the enveloped parasitoid, 1565 adults emerged from the check paper $\left(4 \mathrm{~cm}^{2}\right)$ having Sitotroga eggs harbouring the parasitoid pupae. The papers treated with water produced 1540 adults, which represents $1.60 \%$ reduction as compared to the check. In case of zink sulphate treatment, 1505 adults emerged (with $3.83 \%$ reduction). The emerging numbers for sulphur, potassium sulphate, urea and Fuji-1 treatments were 1500, 1470 and 1455 parasitoid adults with 4.15, 6.07, 5.75 and $7.03 \%$ reductions as compared to the check, respectively. However, the paper cards treated with the insecticide, Malathion produced for 1285 adults, which represents $17.89 \%$ reduction.

When the paper having $T$. evanescens pupae were subjected to the abovementioned treatments without envelopes, values of reductions relatively increased; $1.27,7.96,6.37,8.60,6.37$ and $9.24 \%$ for the treatments of water, zink sulphate, sulphur, potassium sulphate, urea and Fuji-1, respectively. In case of Malathion, the treated cards without envelopes did not emerge to any of the parasitoid adults which means that this insecticide killed completely the pupae of Trichogramma before adult emergence.

On the other hand, when the emerging $T$. evanescens adults were treated with different chemicals, all parasitoid individuals were killed, even when treated with tap water. 
These findings are in agreement with those of Suh et al (2000) who reported that all tested insecticides, with the exception of methoxyfenozide and tebufenozide, adversely affected $T$. evanescens emergence from Helicoverpa zea host eggs. The results of inundative releases of $T$. evanescens to control pests are sometimes variable. King et al (1984) reported that some of this variability could be attributed to the use of broadspectrum insecticides. In such concern, Bull and Coleman (1985) have shown that Trichogramma spp wasps are highly susceptible to most broadspectrum insecticides.

\section{Lareg-scale fields treated with $T$. evanescens and insecticides:}

Five rice fields of variable areas, sown at different locations, were assigned to compare the efficiency of $T$. evanescens release with that of insecticide treatment against the rice stem borer infestation (Tables $4 \& 5$ ). Mansoura, Manzala and Talkha (Dakahlia Governorate) fields suffered 10.22, 9.15 and $12.31 \%$ dead hearts in case of check (untreated) fields. These levels were reduced to 1.10, 2.17 and $0.50 \%$ dead hearts (with corresponding values of reductions of $89.24,76.28$ and $95.94 \%$, respectively) in case of $T$. evanescens release. When carbofuran (the recommended insecticide) was used at a rate of $4 \mathrm{~kg} /$ fed as the growers usually apply, the dead heart percentages were reduced to $5.23,4.25$ and $4.19 \%$ (with corresponding values of reductions of $48.83,53.55$ and 65.96 $\%$, respectively). The same trend was found at El-Riad (Kafr El-Sheikh) rice fields, which suffered 8.50 and Qutour (Gharbia) $2.10 \%$ dead hearts in case of check, and were reduced to $1.30 \& 0.20 \%$ with $T$. evanescens release and to 3.21 and $0.75 \%$ with insecticide application. The corresponding values of dead heart reduction were $84.71 \& 90.48$ in case of $T$. evanescens, and were $62.24 \& 64.29 \%$ in case of insecticide application. Over the locations, varieties and treated areas, the averages of dead hearts were 8.46, 1.05 and $3.53 \%$ for the check, $T$. evanescens and insecticide treatments, respectively. Thus, the reductions due to $T$. evanescens release were greater $(87.33 \%)$ than that of insecticide treatment $(58.97 \%)$.

Table (3): Effect of certain chemicals on the survival of T. evanescens

\begin{tabular}{|l|c|c|c|c|c|c|c|}
\hline \multirow{2}{*}{ Treatment } & \multirow{2}{*}{$\begin{array}{c}\text { Rate / } \\
\text { one liter } \\
\text { of water }\end{array}$} & $\begin{array}{c}\text { With envelope } \\
\text { emerging } \\
\text { parasitoids }\end{array}$ & $\begin{array}{c}\text { No } \\
\text { Reduction }\end{array}$ & $\begin{array}{c}\text { Wo. of } \\
\text { emerging } \\
\text { parasitoids }\end{array}$ & $\begin{array}{c}\% \\
\text { Reduction }\end{array}$ & $\begin{array}{c}\text { No. of alive } \\
\text { parasitoids }\end{array}$ & $\begin{array}{c}\% \\
\text { Reduction }\end{array}$ \\
\hline Check (untreated) & ---- & 1565 & --- & 1570 & ---- & 1560 & ---- \\
Water & ---- & 1540 & 1.60 & 1550 & 1.27 & 0 & 100 \\
Zinkc sulphate & $20 \mathrm{~g}$ & 1505 & 3.83 & 1445 & 7.96 & 0 & 100 \\
Sulphur & $20 \mathrm{~g}$ & 1500 & 4.15 & 1470 & 6.37 & 0 & 100 \\
Potassium & $20 \mathrm{~g}$ & 1470 & 6.07 & 1435 & 8.60 & 0 & 100 \\
sulphate & $20 \mathrm{~g}$ & 1475 & 5.75 & 1470 & 6.37 & 0 & 100 \\
Urea & $2.5 \mathrm{ml}$ & 1455 & 7.03 & 1425 & 9.24 & 0 & 100 \\
Fuji-1 & $2 \mathrm{ml}$ & 1285 & 17.89 & 0 & 100.00 & 0 & 100 \\
Malathion & & & & & & & \\
\hline
\end{tabular}


Table (4): Dead heart levels in rice fields due to rice stem borer, $C$. agamemnon infestation as influenced by $T$. evanescens and insecticide applications (2008).

\begin{tabular}{|c|c|c|c|c|c|c|c|}
\hline Location & Variety & $\begin{array}{c}\text { Area } \\
\text { (feddan) }\end{array}$ & $\begin{array}{c}\text { Check } \\
\text { (untreated) }\end{array}$ & \multicolumn{2}{|c|}{\begin{tabular}{|c|} 
Treated with \\
\end{tabular}} & \multicolumn{2}{|c|}{\begin{tabular}{|c|} 
Reduction $\%$ due to \\
Trichogrammalnsecticide \\
\end{tabular}} \\
\hline $\begin{array}{l}\text { Mansoura } \\
\text { (Dakahlia) } \\
\text { Manzala } \\
\text { (Dakahlia) } \\
\text { Talkha } \\
\text { (Dakahlia) } \\
\text { El-Riad } \\
\text { (Kafr El- } \\
\text { Sheikh) } \\
\text { Qutour } \\
\text { (Gharbia) }\end{array}$ & $\begin{array}{l}\text { Egyptian } \\
\text { Yasmin } \\
\text { Giza } \\
178 \\
\text { Hybrid 1 } \\
\text { Hybrid 1 } \\
\text { Sakha } \\
104\end{array}$ & $\begin{array}{c}30 \\
8 \\
5 \\
7 \\
2\end{array}$ & $\begin{array}{c}10.22 \\
9.15 \\
12.31 \\
8.50 \\
2.10\end{array}$ & $\begin{array}{l}1.10 \\
2.17 \\
0.50 \\
1.30 \\
0.20\end{array}$ & $\begin{array}{l}5.23 \\
4.25 \\
4.19 \\
3.21 \\
0.75\end{array}$ & $\begin{array}{l}89.24 \\
76.28 \\
95.94 \\
84.71 \\
90.48\end{array}$ & $\begin{array}{l}48.83 \\
53.55 \\
65.96 \\
62.24 \\
64.29\end{array}$ \\
\hline $\begin{array}{c}\text { Total / } \\
\text { Average }\end{array}$ & -- & 52 & 8.46 & 1.05 & 3.53 & 87.33 & 58.97 \\
\hline
\end{tabular}

Table (5): White head levels in rice fields due to rice stem borer, $C$. agamemnon infestation as influenced by $T$. evanescens and insecticide applications (2008).

\begin{tabular}{|c|c|c|c|c|c|c|c|}
\hline Location & Variety & $\begin{array}{c}\text { Area } \\
\text { (feddan) }\end{array}$ & $\begin{array}{c}\text { Check } \\
\text { (untreated) }\end{array}$ & \multicolumn{2}{|c|}{ Treated with } & \multicolumn{2}{|c|}{\begin{tabular}{|c|} 
Reduction $\%$ due to \\
Trichogrammalnsecticide
\end{tabular}} \\
\hline $\begin{array}{l}\text { Mansoura } \\
\text { (Dakahlia) } \\
\text { Manzala } \\
\text { (Dakahlia) } \\
\text { Talkha } \\
\text { (Dakahlia) } \\
\text { El-Riad } \\
\text { (Kafr El- } \\
\text { Sheikh) } \\
\text { Qutour } \\
\text { (Gharbia) }\end{array}$ & $\begin{array}{l} \\
\text { Egyptian } \\
\text { Yasmin } \\
\text { Giza } \\
178 \\
\text { Hybrid } 1 \\
\text { Hybrid } 1 \\
\text { Sakha } \\
104\end{array}$ & $\begin{array}{c}30 \\
8 \\
5 \\
7 \\
2\end{array}$ & $\begin{array}{c}14.09 \\
8.12 \\
20.25 \\
16.33 \\
6.41\end{array}$ & $\begin{array}{l}0.60 \\
0.40 \\
0.40 \\
2.00 \\
0.30\end{array}$ & $\begin{array}{l}8.11 \\
6.17 \\
7.32 \\
8.15 \\
3.14\end{array}$ & $\begin{array}{l}95.74 \\
95.07 \\
98.02 \\
87.75 \\
95.32\end{array}$ & $\begin{array}{l}42.44 \\
24.01 \\
63.85 \\
50.09 \\
51.01\end{array}$ \\
\hline $\begin{array}{c}\text { Total / } \\
\text { Average }\end{array}$ & -- & 52 & 13.04 & 0.74 & 6.58 & 94.38 & 46.28 \\
\hline
\end{tabular}

The levels of white heads due to $T$. evanescens and insecticide applications are shown in Table (5). However, the percentages of white heads were too much higher than those of dead hearts, which could be explained that the tested cultivars are more sensitive to borer infestation at heading stage than at tillering stage. The levels of white heads in the check treatments were $14.09,8.12,20.25,16.33$ and $6.41 \%$ at Mansoura, Manzala, Talkha, El-Riad and Kotor, respectively. The corresponding reductions were 95.74, 95.07, 98.02, 87.75 and $95.32 \%$ in case of $T$. evanescens and were $42.44,24.01,63.85,50.09$ and 51.01 in case of carbofuran, respectively.

Over the locations, varieties and treated areas, the average white head level of $13.04 \%$ at the check treatments was 13.4, and reduced by $94.38 \%$ in case of $T$. evanescens and by $46.28 \%$ in case of the insecticide (carbofuran).

Since the rice growers use sometimes foliar insecticides to control insect pests, it has become necessary to find ways to stop such practices to 
conserve the natural enemies. Suh (2000) indicated that most of the foliar insecticide applications are toxic to many nontarget organisms, including predators and parasitoids.

Rice yield, and cost of stem bore control either by $T$. evanescens or by insecticide (Furadan) are presented in Table (6). In all cases, rice varieties treated with $T$. evanescens yielded more than those treated with the insecticide, 3.20, 4.10, 5.60, 5.40, and $4.10 \mathrm{t} /$ fed for the parasitoid, and 2.40, $3.30,4.80,4.60$, and $4.00 \mathrm{t} /$ fed for chemical control, respectively. This shows the efficiency of the new technique (biological control) to control the rice stem borer as compared to the conventional technique (chemical control). One more advantage for the biological control is the cost of application per feddan. Data in Table (6) show that the cost of one feddan by $T$. evanescens is only 30 L.E. throughout the rice season(including two releases), while that of chemical control is $120 \mathrm{~L}$.E. (for $4 \mathrm{~kg}$ Furadan). The latter insecticide was usually used by the rice growers. However, the recommended dose of Furadan is $6 \mathrm{~kg} / \mathrm{fed} /$ application which equals 180 L.E. in average. Sometimes, the growers may need two Furadan applications, which doubles the cost for 360 L.E. / feddan / season.

Table (6): Rice yield of different varieties as influenced by type of rice stem borer control, and of pest control

\begin{tabular}{|l|l|c|c|}
\hline \multirow{2}{*}{ Location } & \multirow{2}{*}{ Variety } & \multicolumn{2}{c|}{ Yield (t / fed) } \\
\cline { 3 - 4 } & & Trichogramma & Insecticide \\
\hline \multirow{2}{*}{ Mansoura (Dakahlia) } & Egyptian Yasmin & 3.20 & 2.40 \\
Manzala (Dakahlia) & Giza 178 & 4.10 & 3.30 \\
Talkha (Dakahlia) & Hybrid 1 & 5.60 & 4.80 \\
El-Riad (Kafr El-Sheikh) & Hybrid 1 & 5.40 & 4.60 \\
Qutour (Gharbia) & Sakha 104 & 4.10 & 4.00 \\
\hline Pest control cost (L.E. / & & 30 & $120^{*}$ \\
\hline \multicolumn{1}{|c|}{ fed) } & - & 30 & \\
\hline
\end{tabular}

- $\quad$ Two applications of Furadan (each at a rate of $2 \mathbf{~ k g ~ / ~ f e d ) . ~ T h e s e ~ d o s e s ~}$ are less than the recommended dose; $6 \mathrm{~kg} / \mathrm{fed} /$ application.

\section{REFERENCES}

Anonymous (1999). IPM in cotton win approval. Biocontrol News and Information, 20 (2).

Anonymous (2005). Control of white stem borer in rice using Trichogramma japonicum Ashmead. Philippine Council for Agriculture, Forestry and Natural Resources Research and Development (PCARRD), Highlights, Los Banos, Laguna.

Anonymous (2007). Entomology report. The $12^{\text {th }}$ workshop of Rice Research and Training Center, Field Crops research Institute, Agricultural Research Center, Egypt. 
Assady, H.B. and I.N. Navai (1995). Effects of rearing conditions on the efficacy of Trichogramma against rice stem borer (Chilo suppressalis) and green rice semilooper (Naranga aenescens) in Mazandaran. Trichogramma News, 8 (2): 33.

Borah, R.K. (1994). Parasitization efficacy of Trichogramma japonicum on rice stem borer in Assam. Annals of Agricultural Research, 15 (1): 124125.

Bull, D.L., and R.J. Coleman (1985). Effects of pesticides on Trichogramma spp. Southwest. Entomol. Suppl. 8: 156-168.

Feng, J. (1996). The effect and influence factors on the use of Trichogramma dendrolimi to control Ostrinia furnacalis. Entomological East China, 5: 45-50.

King, E.G., L.F. Bouse, D.L. Bull, W.A. Dickerson, W.J. Lewis, P. Liapis, J.D. Lopez, R.K. Morrison, and J.R. Phillips (1984). Potential for management of Heliothis spp. in cotton by augmentative release of Trichogramma pretiosum, pp. 232-236. In proceedings, Beltwide Cotton Council, Memphis, TN.

Marub, E. (1993). YRSB eggs parasitoid potential on different rice varieties in an IPM. llum Pertania, 5 (3): 645-656.

Sherif, M.R., A.S. Hendawy and M.M. El-Habashy (2008). Utilization of Trichogramma evanescens (Ashmead) for controlling rice stem borer, Chilo agamemnon Bles. in rice fields in Egypt. Proceeding of $2^{\text {nd }}$ Arab Conference of Applied Biological Pest Control. Egypt. J. Biol. Pest Control, 18 (1): 11-16.

Soliman, A.M. and M.A. Ewaise (1997). Evaluation of Trichogramma evanescens parasitoid as compared with recommended Furadan insecticide against Chilo agamemnon Bles. in rice field. Egypt. J. Agric. Res., 75 (1): 105-110.

Suh, C.P., D.B. Orr and J.W. Van Duyn (2000). Effect of insecticides on Trichogramma exiguum (Trichogramatidae: Hymenoptera) preimaginal development and adult survival. J.Econ.. Entomol., 93 (3): 577-583.

Tan, Y.Q. (1999). Present status and prospect in Trichogramma application in Heilongjiang Province. Chinese Agric. Sci. Bull., 15: 50-51.

Wang, Z.Y., He, K.L., Zhao, J.Z. and Zhou, D.R. (2003). Implementation of integrated pest management in China. In " Integrated Pest Management in the Global Arena" (k. M. Maredia, D. Dakouo, and D. Mota-Sanchez, Eds.), pp. 197-207. CABI Publishing.

Wu, L., He, N.P., and D.W. Hou (2001). Studies on controlling effect of Trichogramma chilonis to corn borer. J. Jilin Agric. Sci., 26: 35-37. 
المواعيد المناسبة لإطلاق طفيل التريكوجرامـا لمكافحسة ثاقبـة سـاق الأرز وتـأثير رش بعض المركبات الكيماوية على حياة الطفيل

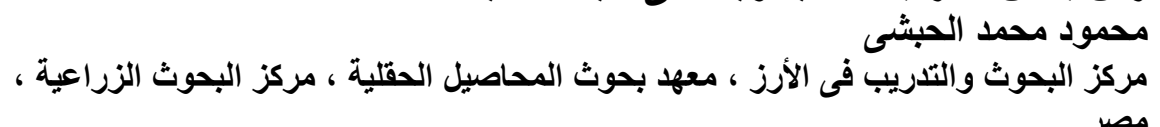

أطلق طفيل التريكوجر اما فى مو اعيد مختلفة فى حقول الأرز لمكافحة ثاقبة ساق الأرز.

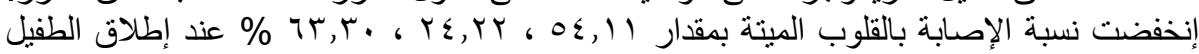

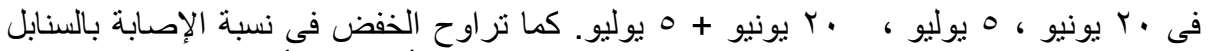

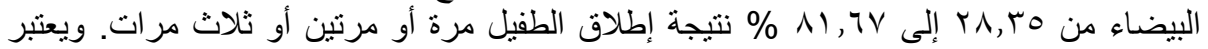

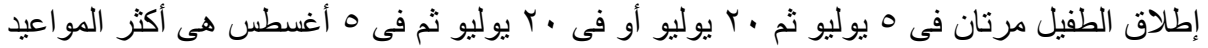

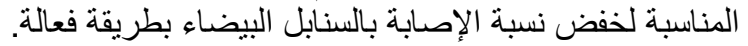

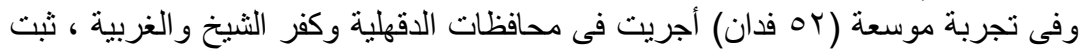

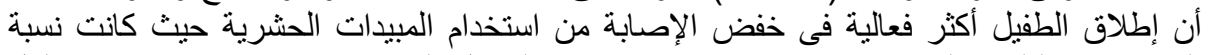

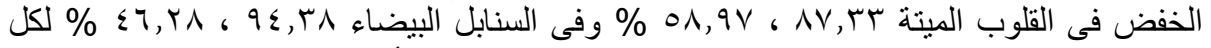

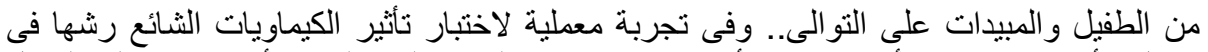

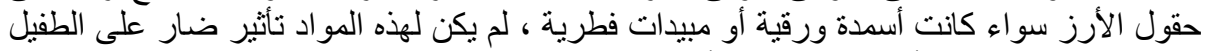

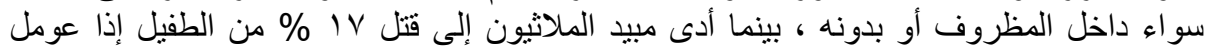

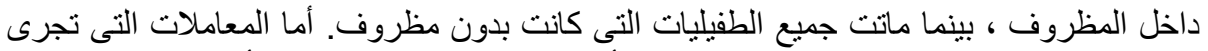

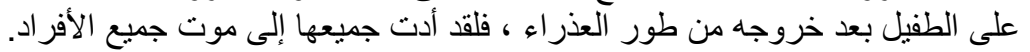

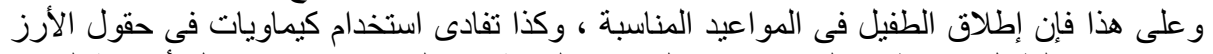

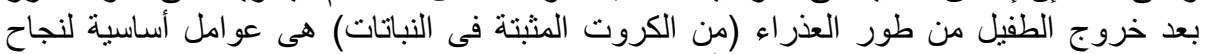
استخدام طفيل التريكوجر الما فى حقور العزل الأرز 